\title{
Uji Efek Antiinflamasi Kombinasi Ekstrak Etanol Daun Gymnanthemum amygdalinum Del. Dan Elaeis guineensis J acq.
}

\author{
Wahyudi ${ }^{1}$, Masnawati ${ }^{2}$, \& I smayuni ${ }^{3}$, Sofia Rahmi ${ }^{1}$, Syukur \\ Berkat Waruw ${ }^{1}$ \\ ${ }^{1}$ Departemen Farmakologi, Fakultas Farmasi, Institut Kesehatan Deli \\ Husada \\ 2 Fakultas Farmasi, Institut Kesehatan Deli Husada \\ 3 Departemen Kimia, Fakultas Farmasi, Institut Kesehatan Deli Husada \\ e-mail: wahyudiapt2016@gmail.com
}

DOI : https://doi.org/10.35451/jfm.v3i1.377

\begin{abstract}
:
Inflammation is a response from the body to injury or infection, flavonoids contained in Gymnanthemum Amygdalinum Del. and Elaeis Guineensis Jacq. have anti-inflammatory effects. This study aims to examine the anti-inflammatory effects of a combination of ethanol extracts of Gymnanthemum Amygdalinum Del. And Elaeis Guineensis Jacq. on white rat foot edema which is induced by carrageenan $1 \%$ subplantar, and effective dosage as anti-inflammatory. The extract was made by maceration method using $96 \%$ ethanol solvent. The antiinflammatory effect test was divided into 5 treatment groups. The first group (negative control) was given $0.5 \% \mathrm{CMC}$ Na suspension, the group (positive control) was given diclofenac Na suspension $2.25 \mathrm{mg} /$ $\mathrm{kg}$ bw, and the suspension group was a combination of African leaf extract (Gymnanthemum Amygdalinum Del.) And palm oil leaves ( Elaeis Guineensis Jacq.) Dose $200+62.5 \mathrm{mg} / \mathrm{kg}$ bw, $400+125 \mathrm{mg} /$ $\mathrm{kg} \mathrm{bw}$, and $800+250 \mathrm{mg} / \mathrm{kg}$ bw. Inflammation volume measurements were measured using a pletismometer for 180 minutes at 30 minute intervals after 1\% carrageenan was induced. The results showed that negative controls had significant differences with other treatment groups which did not show anti-inflammatory effects. In conclusion, the suspension of a combination of ethanol extract of African leaves and palm oil leaves has an effective anti-inflammatory effect at a dose of $800+250 \mathrm{mg} / \mathrm{kg}$ bw.
\end{abstract}

Keywords: Gymnanthemum amygdalinum, Elaeis guineensis, Inflammation 


\section{PENDAHULUAN}

Inflamasi adalah suatu respon dari tubuh terhadap adanya cedera maupun infeksi. Penyebab inflamasi antara lain mikroorganisme, trauma mekanis, zat-zat kimia, dan pengaruh fisika (Rathnavelu, 2016). Rangsangan fisik atau kimiawi yang merusak menyebabkan pelepasan mediator inflamasi seperti histamin, serotonin, bradikinin, prostaglandin dan lain-lain yang menimbulkan reaksi radang seperti rubor (kemerahan), kalor (panas), dolor (nyeri), dan turgor (pembengkakan) (Kohli K,2015).

Obat anti inflamasi non-steroid (AINS) adalah obat yang digunakan untuk meredakan nyeri dan inflamasi. Beberapa produk AINS diantaranya adalah diklofenak, asam mefenamat, ibuprofen, piroksikam, meloksikam. (Rathnavelu, 2016). Obat ini memiliki efek analgesic dan antiinflamasi, mekanisme kerjanya adalah dengan menghambat sintesis prostaglandin, mediator yang berperan penting dalam proses terjadinya inflamasi, nyeri dan demam (Nugroho, A, 2017).

Penggunaan tumbuhan obat di indonesia dalam upaya pemeliharaan kesehatan, maupun sebagai pengobatan cenderung terus meningkat. (Dalimartha $S$, 2010). Tanaman yang dapat dimanfaatkan untuk pengobatan antiinflamasi adalah daun afrika dan daun kelapa sawit. Sebagian masyarakat telah memanfaatkan daun afrika dan daun kelapa sawit sebagai tanaman yang dapat menurunkan peradangan (Hariana Arief, 2013).

Elaeis guineensis Jacq. berasal dari daerah hutan hujan tropis khatulistiwa Afrika, tepatnya di sepanjang teluk guinea (Naher dkk, 2013). Hasil penelitian menunjukkan bahwa daun E. Guineensis dan jusnya efektif menyembuhkan luka (Sasidharan dkk, 2012). Ekstrak daun kelapa sawit dosis $150 \mathrm{mg} / \mathrm{kgbb}$ menunjukkan aktivitas proinflamasi yang signifikan dengan meningkatkan $46 \%$ efek pemulihan inflamasi fase lanjut. Sementara pada dosis tinggi, peradangan ditekan secara signifikan sebelumnya ke jam keenam dibandingkan dengan kelompok lain. Hasil ini menunjukkan bahwa ekstrak daun kelapa sawit memiliki efek anti inflamasi yang kuat (Anyanji dkk, 2013).

Berdasarkan uraian diatas, maka penulis ingin melakukan penelitian lebih lanjut dengan judul “ $\mathrm{Uji}$ Efek Antiinflamasi Kombinasi Ekstrak Etanol Daun Gymnanthemum amygdalinum Del. Dan Elaeis guineensis J acq.

\section{METODE}

Metode penelitian yang digunakan dalam penelitian ini adalah bersifat eksperimental. Hewan percobaan yang digunakan tikus putih jantan, berusia 2-3 bulan dengan berat badan 150-200 g.

\section{Tempat penelitian}

Pembuatan ekstrak etanol daun afrika dan ekstrak etanol daun kelapa sawit dilakukan di laboratorium fitokimia, dan uji efek antiinflamasi pada tikus di laboratorium farmakologi Institut Kesehatan Deli Husada Deli Tua.

\section{Waktu penelitian}

Penelitian ini akan dilaksanakan pada bulan januari 2019 sampai dengan selesai.

\section{Pengujian efektivitas antiinflamasi}

Sebelum pengujian, tikus dipuasakan selama 8 jam (tidak makan tetapi masih tetap diberi minum). Hewan dikelompokkan kedalam 5 kelompok, yang masing-masing kelompok terdiri dari 3 ekor tikus, yaitu:

Kelompok I : Kontrol positif suspensi natrium diklofenak $2,25 \mathrm{mg} / \mathrm{kg}$ bb.

Kelompok II : Kontrol negatif Suspensi CMC Na 0,5\%

Kelompok III : Suspensi kombinasi EEDA dan EEDKS dosis $200+62,5 \mathrm{mg} / \mathrm{kg}$ bb 
Kelompok IV : Suspensi kombinasi EEDA dan EEDKS dosis $400+125 \mathrm{mg} / \mathrm{kg}$ bb

Kelompok V : Suspensi kombinasi EEDA dan EEDKS dosis $800+250 \mathrm{mg} / \mathrm{kg} \mathrm{bb}$

Pada hari pengujian kaki kiri tikus dimasukkan ke dalam sel yang berisi cairan khusus yang ada pada alat pletismometer sampai cairan naik pada garis batas atas, kemudian pedal ditahan, dicatat angka pada monitor sebagai volume awal (Vo) yaitu volume kaki sebelum diberi obat dan diinduksi larutan $\lambda$-karagenan.

Masing-masing telapak kaki tikus disuntik secara intraplantar dengan $0,01 \mathrm{ml}$ larutan $\lambda$-karagenan $1 \%$. Setelah 30 menit, masing-masing tikus diberi suspensi bahan uji secara oral sesuai dengan kelompoknya. Kemudian dilakukan pengukuran setiap 30 menit, dengan cara mencelupkan kaki tikus pada sel pletismometer yang berisi cairan khusus sampai larutan mencapai garis batas atas, dan pedal ditahan. Dicatat angka pada monitor. Perubahan volume cairan yang terjadi dicatat sebagai volume telapak kaki tikus (Vt). Pengukuran dilakukan setiap 30 menit selama 180 menit. Dan tiap kali pengukuran larutan sel tetap dicukupkan sampai garis tanda atau garis merah bagian atas sel dan pada menu utama ditekan tombol nol, dan juga kaki tikus dikeringkan sebelumnya (Juheini, 1990).

Volume radang adalah selisih volume kaki tikus setelah dan sebelum disuntikkan $\lambda$-karagenan $1 \%$. Pada waktu pengukuran, volume cairan pada sel pletismometer sama setiap kali pengukuran dan tanda batas pada kaki tikus harus jelas, kaki tikus harus tercelup sampai batas yang dibuat (Juheini, 1990).

\section{HASI L DAN PEMBAHASAN}

\section{Pengujian efek antiinflamasi}

Penelitian ini dilakukan dengan membandingkan volume edema kaki tikus yang diinduksi karagenan sebelum dan sesudah perlakuan. Alat yang digunakan untuk mengukur edema adalah pletismometer (Ugo Basile) dengan prinsip pengukuran berdasarkan hukum Archimedes. Hewan uji dibagi menjadi lima kelompok yaitu yang diberi suspensi kombinasi EEDA dan EEDKS dosis 200+62,5 $\mathrm{mg} / \mathrm{kg} \mathrm{bb}$, dosis $400+125 \mathrm{mg} / \mathrm{kg} \mathrm{bb}$, dosis $800+250 \mathrm{mg} / \mathrm{kg}$ bb dengan kelompok kontrol (-) yang diberi $\mathrm{Na}-\mathrm{CMC} 0,5 \%$ dan natrium diklofenak sebagai kontrol (+).

Berdasarkan perubahan volume kaki, dapat dihitung persen radang rata-rata. Kelompok persen radang yang lebih kecil dari kontrol negatif menunjukkan bahwa sediaan bahan uji mampu menekan radang yang disebabkan oleh $\lambda$-karagenan. Suspensi natrium diklofenak $2,25 \mathrm{mg} / \mathrm{kg}$ bb memiliki persen radang yang lebih kecil dari pada suspensi kombinasi EEDA dan EEDKS $800+250 \mathrm{mg} / \mathrm{kg} \mathrm{bb}, 400+125 \mathrm{mg} / \mathrm{kg}$ bb, dan $200+62,5 \mathrm{mg} / \mathrm{kg}$ bb. Kombinasi EEDA dan EEDKS $800+250 \mathrm{mg} / \mathrm{kg}$ bb mempunyai

persen radang yang lebih kecil dari pada kombinasi EEDA dan EEDKS $400+125 \mathrm{mg} / \mathrm{kg}$ bb, dan 200+62,5 mg/kg bb. Data hasil pengukuran persen radang dapat dilihat pada Tabel 1 dibawah ini.

Pada gambar 1 dapat dilihat bahwa semua kelompok dosis memiliki persen radang rata-rata yang lebih kecil dari kelompok Na CMC dari menit ke-30 sampai menit ke-180. Dapat dilihat suspensi $\mathrm{Na}$ diklofenak dan suspensi kombinasi EEDA dan EEDKS dosis $800+250 \mathrm{mg} / \mathrm{kg}$ bb memiliki rata-rata persen radang terendah. Pada menit ke-180 semua suspensi kombinasi EEDA dan EEDKS telah mengalami penurunan persen radang. Dan dapat dilihat pada suspensi kombinasi EEDA dan EEDKS dosis $800+250 \mathrm{mg} / \mathrm{kg}$ bb dan suspensi $\mathrm{Na}$ diklofenak tidak mengalami peningkatan persen radang yang terlalau tinggi.

Pada gambar 1 dapat dilihat bahwa semua kelompok dosis memiliki persen radang rata-rata yang lebih kecil dari kelompok Na CMC dari menit ke-30 sampai menit ke-180. Dapat dilihat suspensi $\mathrm{Na}$ diklofenak dan suspensi kombinasi EEDA dan EEDKS dosis $800+250 \mathrm{mg} / \mathrm{kg}$ bb memiliki 
rata-rata persen radang terendah. Pada menit ke-180 semua suspensi kombinasi EEDA dan EEDKS telah mengalami penurunan persen radang. Dan dapat dilihat pada suspensi kombinasi EEDA dan EEDKS dosis $800+250 \mathrm{mg} / \mathrm{kg}$ bb dan suspensi $\mathrm{Na}$ diklofenak tidak mengalami peningkatan persen radang yang terlalau tinggi.

Tabel 1. Persentase radang rata-rata setelah perlakuan

\begin{tabular}{|c|c|c|c|c|c|c|}
\hline \multirow{2}{*}{ No } & $\begin{array}{c}\text { Waktu } \\
(\text { menit) }\end{array}$ & $\begin{array}{c}\text { CMC Na } \\
0,5 \%\end{array}$ & $\begin{array}{c}\text { Natrium } \\
\text { diklofenak } \\
2,25 \\
\text { mg/kgbb }\end{array}$ & $\begin{array}{c}\text { EEDA dan } \\
\text { EEDKS } \\
200+62,5 \\
\text { mg/kgbb }\end{array}$ & $\begin{array}{c}\text { EEDA dan } \\
\text { EEDKS } \\
400+125 \\
\mathrm{mg} / \mathrm{kgbb}\end{array}$ & $\begin{array}{c}\text { EEDA dan } \\
\begin{array}{c}\text { EEDKS } \\
800+250 \\
\mathrm{mg} / \mathrm{kgbb}\end{array}\end{array}$ \\
\hline 1 & 30 & 133,17 & 90,40 & 114,39 & 96,39 & 67,93 \\
\hline 2 & 60 & 130,14 & 80,19 & 106,91 & 85,21 & 62,42 \\
\hline 3 & 90 & 127,88 & 65,43 & 89,33 & 73,00 & 52,81 \\
\hline 4 & 120 & 127,4 & 40,1 & 79,12 & 59,92 & 46,77 \\
\hline 5 & 150 & 125,65 & 26,88 & 67,75 & 45,55 & 38,60 \\
\hline 6 & 180 & 23,52 & 15,69 & 54,83 & 35,07 & 29,32 \\
\hline
\end{tabular}

\section{Persentase inhibisi radang}

Berdasarkan hasil perhitungan persen inhibisi radang rata-rata kaki tikus menunjukkan kelompok percobaan yang diberi suspensi Nadiklofenak memberikan hasil persentase terbesar yaitu $87,29 \%$, diikuti oleh kelompok suspensi kombinasi EEDA dan EEDKS $800+250 \mathrm{mg} / \mathrm{kg}$ bb dengan hasil persentase $76,26 \%$, dan suspensi kombinasi EEDA dan EEDKS $400+125 \mathrm{mg} / \mathrm{kg}$ bb dengan persentase $71,60 \%$. Untuk melihat hasil inhibisi radang rata-rata kaki tikus lebih jelas maka dibuat grafik. Grafik hasil pengukuran rata-rata dapat dilihat pada gambar 1 .

Gambar 1. Grafik pengukuran rata-rata persen inhibisi radang.

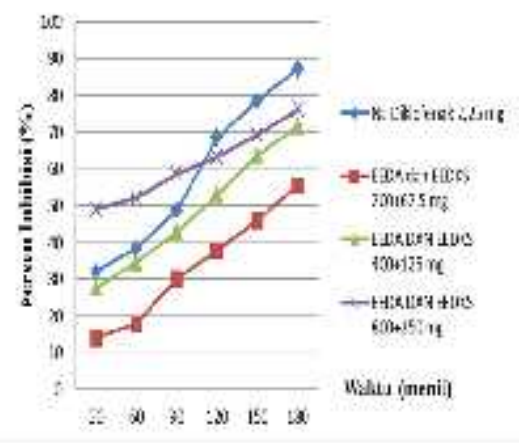

\section{Analisis Data}

Data hasil uji statistik One Way Anova nilai AUC menunjukkan hasil yang signifikasi yaitu nilai $p<0,05$ menunjukkan bahwa ada pengaruh pemberian suspensi kombinasi kombinasi EEDA dan EEDKS terhadap penurunan volume udem tikus yang diinduksi karagenan. Dengan uji tukey's b dapat diketahui perbedaan yang tidak signifikan (tidak berbeda makna) antara nilai AUC kelompok 5 yang diberikan suspensi kombinasi EEDA dan EEDKS dosis $800+250$ $\mathrm{mg} / \mathrm{kg}$ bb dengan kelompok 2 yang diberikan natrium diklofenak dosis $2,25 \mathrm{mg} / \mathrm{kg}$ bb. Hasil ini menunjukkan bahwa suspensi kombinasi EEDA dan EEDKS dosis $800+250 \mathrm{mg} / \mathrm{kg}$ bb memiliki efek yang sama secara statistik dengan natrium diklofenak. Jadi semakin tinggi dosis herba daun afrika dan daun sawit dalam etanol $96 \%$ maka efek antiinflamasi ekstrak etanol daun afrika dan ekstrak etanol daun kelapa sawit semakin besar hal ini sesuai dengan hasil penelitian yang diekstrak dengan 
Na CMC 0,5\% yang mampu menghambat enzim yang menghasilkan mediator inflamasi.

\section{SI MPULAN DAN SARAN}

\section{Simpulan}

Berdasarkan pengamatan selama penelitian dan pembahasan dapat disimpulkan bahwa:

1. Kombinasi ekstrak etanol daun afrika (EEDA) dan ekstrak etanol daun kelapa sawit (EEDKS) memiliki efek antiinflamasi terhadap tikus putih

2. Kombinasi EEDA dan EEDKS mempunyai efek antiinflamasi yang setara dengan natrium diklofenak.

3. Kombinasi EEDA dan EEDKS dosis $800+250 \mathrm{mg} / \mathrm{kg}$ bb memiliki efek yang paling efektif sebagai antiinflamasi.

\section{Saran}

Disarankan kepada peneliti selanjutnya untuk dapat memformulasi sediaan esktrak ini menjadi bentuk sediaan farmasi tertentu seperti tablet atau sediaan topikal.

\section{DAFTAR PUSTAKA}

Anyanji VU., Mohamed S., Zokti JA., Ado MA. (2013) Antiinflammatory properties of oil palm leaf (Elaeis guineensis Jacq.) extract in aged rats. Int J Pharm Pharm Sci. 5: 134-136.

Dalimartha S. (2010). Atlas Tumbuhan Obat Indonesia, Jilid 5. Jakarta: Pustaka Bunda.

Hariana, A. (2013). Tumbuhan Obat \& Khasiatnya Seri I. Jakarta: Penebar Swedaya Grup.

Juheini. (1990). Efek antiinflamasi Jahe (Zingiber officinale R.) Terhadp Udem Buatan pada Tikus Putih. Majalah Farmakologi dan Terapi Indonesia. 7: 9-14.

Kohli, K., Ali J., Ansari M. J., and Raheman Z. (2015). Curcumin : A Natural
Antiinflamamatory Agent, in Indian Journal of Pharmacology. New Delhi : Jarnia Hamdard University. Pages. 141- 142

Naher L, Yusuf UK, Ismail A, Tan SG, Mondal MMA. Ecological status of Ganoderma and basal stem rot disease of oil palms (Elaeis guineensis Jacq.) AJCS. 2013; 7: 1723-1727.

Nugroho, A. E. (2016). Farmakologi Obatobat Penting dalam Pembelajaranl Imu Farmasi dan Dunia Kesehatan. Yogyakarta: Pustaka Pelajar. Halaman 175, 179.

Rathnavelu, V., Alitheen, N. B. And Sohila, S. (2016). Antiinflammatory and Analgesic Agents fromlndian Medicinal Plants. International Journal of Integrative Biology.

Sasidharan S, Selvarasoo L, Latha LY. (2012). Wound Healing Activity of Elaeis guineensis Leaf Extract Ointment. Int J Mol Sci. 13: 336-347. 